Riwayat draf artikel: Diserahkan, 28-11-2020 Diterima, 17-02-2021

\section{The Implementation of Using Whatsapp and Youtube in FLTM Class: Teacher's Perception}

\author{
Desi $^{1^{*}}$, Titin Rahmiatin ${ }^{2}$, Rahmat Nasrullah ${ }^{3}$ \\ Department of English Language Teaching, Universitas \\ Muhammadiyah Kendari ${ }^{123}$ \\ Email: desy.zabidin97@gmail.com
}

\begin{abstract}
The objective of this study is to find out the teacher's perception on the implementation of using Whatsapp messanger and Youtube in class B 5th semesters of FLTM classroom at Muhammadiyah University students of Kendari. Since teacher's perception has not been investigated thoroughly in the earlier research on the implementation of using WhatsApp and Youtube media as a learning tools. This study employs qualitative study design to find out lecturer's perception in teaching process using Whatsapp and Youtube. The instruments used in this study are documentation and interview and the data are analyzed using data reduction, data display, meaning coding, meaning condensation, meaning interpretation, conclusion drawing and data triangulation. The findings reveal that the teacher considered to implement Whatsapp and Youtube in teaching have several advantages and disadvantages in learning objective and outcomes. This can be viewed in the arrangement of knowledge of subject matter, teacher-students interaction, design of instruction, and course management. Furthermore, teacher's beliefs in using Whatsapp and Youtube in teaching appeared to be strongly connected to the flexibility of teaching and learning process and learning content availability.
\end{abstract}

Keywords: Educational Technology, Freedom to Learn, 4.0 era.

ABSTRAK: Tujuan penelitian ini untuk mengetahui persepsi guru tentang penerapan penggunaan Whatsapp dan Youtube di kelas FLTM, kelas B semester V Universitas Muhammadiyah Kendari. Sejak penerapan penggunaan media WhatsApp dan Youtube sebagai perangkat pembelajaran belum banyak diteliti maka penelitian ini dilakukan. Peneliti menggunakan desain studi kualitatif untuk mengetahui persepsi dosen dalam proses pembelajaran menggunakan Whatsapp dan Youtube. Instrumen yang digunakan dalam penelitian ini adalah dokumentasi dan wawancara. Analisis data menggunakan reduksi data, penyajian data, pengkodean makna, pengembunan makna, interpretasi makna, penarikan kesimpulan dan triangulasi data. Hasil penelitian mengungkapkan bahwa guru yang dinilai menerapkan Whatsapp dan Youtube dalam pembelajaran memiliki beberapa kelebihan dan kekurangan. Hal ini dapat dilihat dari penataan pengetahuan materi pelajaran, interaksi guru-siswa, desain pembelajaran, dan manajemen mata kuliah. Selain itu, keyakinan guru dalam menggunakan Whatsapp dan Youtube dalam pengajaran tampaknya sangat terkait dengan fleksibilitas proses belajar mengajar dan ketersediaan konten pembelajaran.

Kata Kunci: Era 4.0, Kebebasan Belajar, Teknologi Pendidikan. 


\section{PENDAHULUAN}

The impact of the use of technology in teaching English is that students can have interesting and empowering learning experiences both inside and outside the classroom that prepare them to become active, creative, knowledgeable, and critical participants in a global networked society (Fry et al., 2003). In addition, professional educators will be individually supported by technology that connects them with data, content, resources, expertise, and learning experiences that enable and inspire more effective teaching for all learners (FAO, 2011). All students and teachers will have access to a comprehensive infrastructure for learning when and where they need it.

The use of technology is one of the language learning tools or as a means for teachers to be able to develop their current teaching methods, using several online applications can motivate students to learn. Prensky (2001) states that all of these students are native speakers of digital computers and the internet. The lives of many students today are filled with technology that gives them mobile access to information and resources that allow them to create multimedia content and share it with the world, and allow them to participate in online social networks where people around the world share ideas, ccollaborate, and learn new things (Tomei, 2010). One of the popular online applications that teachers always use as a learning tool is the WhatsApp messenger application.

The positive impact of using WhatsApp as a learning tool is that students can be motivated to learn, build student enthusiasm for learning, and increase student selfconfidence (Kheryady, 2017). This helps students to develop their writing, allow students to learn from the mistakes of their peers, Among the technical advantages, most students agree that WhatsApp is easy to use and available and can be downloaded easily. Along with these advantages, there were many challenges faced by students and facilitators while carrying out TL activities via WhatsApp.

Although students agree that smartphones are a prerequisite for WhatsApp, teachers must always be careful and patient to control groups and students who do not have smartphones cannot access the WhatsApp application. According to (Bouhnik and Deshen, 2014) "The fact is that not all students have access to the application, some students do not participate in discussions and if there is no Wi-Fi they have to use a package with cellular data which costs a little more than without cellular data". In connection with the above problems, therefore the authors are motivated to conduct more in-depth research on teacher perceptions regarding the use of WhatsApp in the learning process. This study aims to determine teacher perceptions of the use of WhatsApp media in the context of online learning as a learning tool in the English Department of Muhammadiyah University of Kendari.

\section{METHOD}

This research uses a qualitative approach design "case study". This study aims to determine how teachers perceive the application of WhatsApp Messenger and YouTube in the FLTM class. A qualitative approach is an approach in which the questioner often makes knowledge claims based on a constructivist or advocacy/participatory perspective: perspective or both (Creswell, 2003, p. 18). Recent 
study, data collection using interviews and documentation and analyzed using data reduction, data presentation, drawing conclusions and data triangulation. And the data from the analysis of this study are described in four aspects of teaching, knowledge of subject matter, teacher-student interaction, learning design, and learning management (John Dewey, 2003) to determine teacher perceptions of the advantages and disadvantages of using WhatsApp and YouTube as learning tools.

\section{FINDINGS AND DISCUSSION}

\section{FINDINGs}

The findings show teachers' perception on the implementation of Whatsapp and Youtube at English Department Muhammadiyah University of Kendari have advantages and disadvantages. The findings reveal that the teacher considered to implemented whatsapp and youtube in teaching in response to learning objective and outcomes, which are viewed and analyzed in terms of knowledge of subject matter, teacher-students interaction, design of instruction, and course management. In other words, the findings try to reveal the elements associated with how teachers' perception in the use of Whatsapp and Toutube in the FLTM class listed in the research question. This study is revealed through data collection. Therefore, the writer tries to describe more specifically the findings based on the data collection instruments used in this study.

Table $1 . \quad$ Field Findings

\begin{tabular}{|c|c|}
\hline Advantages & Disadvantages \\
\hline $\begin{array}{l}\text { - Easy to use app to send photos, } \\
\text { videos, documents instantly }\end{array}$ & $\begin{array}{l}\text { - Lack of structure. The teacher cannot see } \\
\text { directly student activities or student expressions } \\
\text { when they respond or provide comments on } \\
\text { learning. }\end{array}$ \\
\hline $\begin{array}{l}\text { A great chat platform to Get } \\
\text { instant responses from teacher } \\
\text { anytime and anywhere. }\end{array}$ & $\begin{array}{l}\text { - The teacher cannot find out whether students } \\
\text { actually watch the teaching material through the } \\
\text { link provided or just join in giving comments }\end{array}$ \\
\hline $\begin{array}{l}\text { Great for two way communication } \\
\text { for teacher and student } \\
\text { interaction, they Can send } \\
\text { unlimited messages in the group } \\
\text { anytime and anywhere. }\end{array}$ & $\begin{array}{l}\text { - only some students actively commented in } \\
\text { online discussions while other students only } \\
\text { listened }\end{array}$ \\
\hline $\begin{array}{l}\text { - Motivate students' enthusiasm in } \\
\text { learning }\end{array}$ & $\begin{array}{l}\text { - WhatsApp and YouTube classes can only be } \\
\text { accessed if the user has an internet data package }\end{array}$ \\
\hline
\end{tabular}

\section{DISCUSSION}

Online learning is being used more and more in higher education. However, for humanities and other loosely content structured areas, online learning can be challenging (FAO, 2011). It has generally been reserved for subject areas including the teaching and learning processes in the tertiary education, where competence is commonly assessed by administering work on which performance is either right or wrong. Furthermore, agreement has not yet been reached on how to best incorporate 
the face-to-face and online teaching resources (Fry et al, 2003). This study examines one approach of implementing web-based instruction to improve undergraduate students' English competence at English Department, Muhammadiyah University, Kendari.

Based on the above finding, in the context of course management, the procedures used in WhatsApp media are almost the same to the ones in the face-toface class, starting from the pre activities, main activities and post activities. This corresponds to what FAO (2011) who asserts that online learning can be challenging since it incorporates both online and offline learning media.

Online learning is a broad, complex, adaptive, and dynamic system that will self-organize and co-evolve. It is made up of at least six various subsystems: the learner, the instructor, the technology, the content, the learning support, and the institution (Fry et al, 2003). Each of these online learning subsystems act within themselves and upon one another in a dynamic and non-linear fashion. Bringing all these dimensions together in this framework can help other instructors in institutions of higher learning to understand, design, and implement online introduction to the teaching and learning processes in the tertiary education.

Viewing a detailed description of online learning designs such as this one may offer other instructors some ideas and insights that might improve similar higher level general education classes (Fry et al, 2003). It is also important to reflect on their own course designs, teaching, and experiences -both as learners and as instructors. Such reflective practices are likely to stimulate innovative thinking, as instructors combine personal experiences from the past, current practices used today, and new approaches encountered in future research into unique blends that fit their academic subject.

Findings indicate that teachers consider implementing WhatsApp messenger in teaching in response to learning objectives and outcomes but this has both advantages and disadvantages. Furthermore, teacher's perception in using whatsapp and youtube in teaching appeared to be strongly connected to the flexibility of teaching and learning process and learning content availability on the teaching and learning processes in the classroom because many learning inputs conveyed through WhatsApp application can be used in the classroom. The use of WhatsApp media can facilitate the face-to-face class and it is treated almost the same as the offline class and teachers' are being responsive, accessible, rapport, timely, clarity and respect involve teacher and student's feelings and emotions. It also involves student's understanding and knowledge of the materials taught by teacher.

Every teacher has perception. They are focused on his/her work, students, subjects, responsibilities (Pajares, 1992). The main formative factors of perception are family, education, culture, society, reflection, life experience, as well as the process of socialization at school. If teacher's perception is that learning basically does not depend on the teacher, there is no need to look for and find new challenges to improve academic achievement and student's motivation. If the teacher's perception is that the result of education process should be significant learning, the new objectives are set and effective teaching methods applied.

However, there are limitations in this study. First, the researcher only focuses on teacher perception "advantages-disadvantages" on the implementation of using 
Whatsapp messenger, second the researcher only uses interviews and documentation in data retrieval, third the research was only able to examine teacher perception "advantages-disadvantages" on the implementation of using Whatsapp messenger in the class of foreign language teaching media (FLTM), not yet on students perception, and last is the study was only conducted in one class; therefore this research was limited by data sources which only involved 1 teacher, so it would be better if the researcher also involved other teachers to get more data.

Referring to the conclusion and limitation of this researcher would like to recommended to the other researchers, who would like to do the same study about teacher perception on the implementation of Whatsaaap messanger and Youtube as a learning tools, the things that have not been answered in this study and can be an interesting point for the next research are as follows. Other researchers can explore more on the effect of online learning towards the more "shy" or "reticent" students to improve their participation in group discussion, or they also explore or investigate more on the effect of online learning towards students' learning achievements compared to the use of offline learning model. Or, even the effect of online learning tools towards students' reading, speaking or writing skills.

Based on the above findings, the pedagogical implications of the use of Whatsapp messanger and Youtube as a learning tools. First, teachers can enhance or improve their teaching skills by carefully selecting which materials or which activities are more appropriate for face-to-face or offline class and which materials or which activities are more appropriate for online class. As such, teachers can maximize the teaching and learning processes and students' learning achievent can also be much better. Second, students can access the large abundant of learning materials from various online sources to supplement the earlier materials. Besides, students are able to create more foreign language teaching media using WhatsApp or YouTube media. Besides, online larning using WhatsApp or YouTube media can also be used by students to sharpen their skills in online discussion to get more comprehension of the learning materials they have not obtained from the face-to-face or offline class.

\section{CONCLUSION}

The findings suggest that the implementation of Whatsapp messanger and Youtube has both advantages and disadvantages. it can also be concluded that teachers are also able to identify and apply the most effective, most appropriate teaching methods in the context of online learning. Not only has the knowledge made teachers' work effective, but also the way of organizing the learning process and updating interdisciplinary links. Achievements of every student are also important to them.

In the context of online learning, teacher can also take care of a positive learning environment. The learning environment is a key component of trust. It is important to create a learning environment where students are not afraid to make mistakes. In this case, mistakes are seen as an essential part of the learning process.

In the context of online learning, searching, finding, creation of feedback in the learning process is essential for teacher. The teacher knows that lesson usually does not occur exactly according to the particular plan; the teacher knows how to guide the 
lesson to reach its objectives. It is important in this process to identify students who have not understood the subject matter. Besides, the teacher perception that all students can become successful students. Beholding teacher's perception, students gain confidence in their own abilities as well.

\section{ACKNOLEDGEMENT}

The researcher presents the sincere appreciation goes to my advisors for their supervision, advice, guidance, and help until the completion of this article.

\section{REFERENCES}

Creswell, John W (2003). Research Design: Qualitative, Quantitative, and Mixed Method Approaches. University of Michigan.

Dan Bouhnik, \& Mor Deshen (2014). WhatsApp goes to school: Mobile instant messaging between teachers and students. Journal of Information Technology Education Research, 13, 217-231.

Dewey, John (2005). The Art of Teaching : Toward Reflective and Imaginative Practice. Researchgate, DOI: 10.4135/9781452232386.

FAO Food and Agriculture Organization of the United Nations (2011). E-learning Methodologies : A Guide For Designing And Developing E-Learning Courses. Federal Ministry of Food, Agriculture and Consumer Protection.

Kheryadi, K (2017). The Implementation of WhatsApp As A Media of English Teaching Language. Loquen, English Studies Journal 10 (2), 1-14.

Pajares M., F. (1992). Teachers' perception and educational research: Cleaning Up a Messy Construct. In: Review of Educational Research. Vol. 62, 3 (pp. 307-332). American Educational Research Association.

Prensky, (2001). Digital Natives and digital immigrants. From on the horizon NCB.

Tomei, Lawrence (2010). ICTs For Modern Educational And Instructional Advancement: New Approaches To Teaching. Information Science Reference, New York. 